\title{
Effect of dietary supplementation of crude microalgal extracts on growth performance, survival and disease resistance of Lates calcarifer (Bloch, 1790) larvae
}

\author{
ADNAN HUSSAIN GORA, K. AMBASANKAR*, K. P. SANDEEP*, SAIMA REHMAN, \\ DEEPAK AGARWAL, IRSHAD AHMAD AND KASILINGAM RAMACHANDRAN \\ Madras Research Centre of ICAR-Central Marine Fisheries Research Insitute, 75, Santhome High Road, Chennai \\ Tamil Nadu - 600 028, India \\ *ICAR-Central Institute of Brachishwater Aquaculture, 75, Santhome High Road, Chennai \\ Tamil Nadu - 600 028, India \\ e-mail: goraadnan@gmail.com
}

\section{ABSTRACT}

\begin{abstract}
The present study aimed to assess growth performance and health status of Lates calcarifer larvae fed with crude microalgal extracts. Larvae weighing $5.96 \pm 0.39 \mathrm{mg}$ were randomly divided into four experimental groups in triplicates, with each replicate having 35 larvae. Four diets formulated to contain 55\% protein and $12 \%$ lipid, were prepared with pigment rich microalgal extracts at $0 \%(\mathrm{~T} 1)$ and $1 \%$ each of crude phycocyanin (T2), chlorophyll (T3) and astaxanthin (T4) extracts. The experiment was carried out in $30 \mathrm{l}$ plastic tanks by feeding experimental diets to satiation. There was no significant difference $(p<0.05)$ in growth performance in larval groups fed different experimental diets. Percentage survival during the feeding experiment was significantly higher in the astaxanthin fed group $(77.14 \pm 1.65)$ and lower in chlorophyll fed group (36.19 \pm 0.95$)$ compared to control group. Cannibalism (\%) was significantly reduced in the treatments fed astaxanthin (7.61 \pm 0.95$)$ and phycocyanin $(8.57 \pm 0.3)$ pigmented diets compared to chlorophyll fed group $(13.33 \pm 0.95)$ and control group. Bacterial challenge with pathogenic Vibrio alginolyticus revealed highest resistance in astaxanthin and phycocyanin fed larvae. The study confirms that astaxanthin and phycocyanin at 1\% dietary levels improve survival and disease resistance in Asian seabass larvae but do not affect growth performance.
\end{abstract}

Keywords: Astaxanthin, Chlorophyll, Larval feed, Lates calcarifer, Microdiets, Phycocyanin

\section{Introduction}

Fish larvae are vulnerable during the first stages of development and are highly responsive to biotic and abiotic conditions. Asian seabass, Lates calcarifer (Bloch, 1790) has altricial ontogenetic development and predatory feeding habit which increases occurrence of coevial cannibalism. The cause of cannibalism is a conglomerate of genetic and behavioural factors and poorly acceptable feeds may enhance, or even trigger cannibalism (Hamre et al., 2013). Mortality is more frequent in the first two months after hatching. The weaning of marine fish larvae towards formulated microdiets is important to simplify the rearing procedures and reduce mortality. Although a number of studies have evaluated the survival and health with respect to various factors like growth rate and stocking density (Barlow et al., 1995; Kailasam et al., 2002; Kailasam et al., 2007), the effect of dietary additives remains largely unknown.

Algae are a group of nonvascular autotrophic organisms that are able to produce a wide range of pigments and bioactive compounds that can be used in aquaculture diets (Spolaore et al., 2006). Astaxanthin is a secondary carotenoid that finds use in aquaculture. Haematococcus pluvialis synthesises astaxanthin in its cysts and has been studied in detail as a commercial source of astaxanthin (Guerin et al., 2003). Phycocyanin is a phycobiliprotein and the major photosynthetic pigment in cyanobacteria (Patil and Raghavarao, 2007). Phycocyanin is not only used as a colouring agent (Yoshida et al., 1996) but also as a therapeutic agent against oxidative stress (Bhat and Madyastha, 2001). Chlorophyll (chl) $a$, is a blue green pigment which, unlike chl b and $\mathrm{c}$, is found in all photosynthetic organisms. Chlorophyll $a$ has been known for its bioactive properties (Dashwood et al., 1998; Simonich et al., 2008). Pigments improve the welfare of aquatic animals during the larval stages. This is mostly reflected in the improvement of survival of larvae (Vassallo-Agius et al., 2001; Chuchird et al., 2015) in culture settings. However, studies evaluating the direct effect of dietary microalgal pigments on the welfare of fish larvae are scarce. Therefore, present study was conducted 
with the objective to evaluate the growth performance, survival, stress resistance and disease resistance of seabass larvae weaned onto microdiets supplemented with crude microalgal extracts. Knowledge of the effect of crude microalgal extracts on these parameters may help to improve survival rates in captive rearing.

\section{Material and methods}

\section{Feed pigments and pigment extraction}

Three different types of natural pigments were used to provide colour to the feed particles. Phycocyanin rich extract, from Spirulina platensis, is dark blue in colour and provides green colour to the feed. Astaxanthin, from H. pluvialis, is red in colour and imparts red colour to the feed. Chlorophyll rich extract, from Chlorella, is blackish green in colour and provides black colour to the feed.

Phycocyanin was extracted from freeze-dried S. platensis (Ocean Nutrition International LLC, USA). The phycocyanin pigment was extracted from the algae by freeze thaw method (Sivasankari et al., 2014). The content of phycocyanin, which could be extracted in the crude extract, was calculated by using the formula (Bennett and Bogorad, 1973):

$$
\mathrm{PC}\left(\mathrm{mg} \mathrm{ml}^{-1}\right)=\frac{\mathrm{A}_{615}-0.474\left(\mathrm{~A}_{652}\right)}{5.34}
$$

where $\mathrm{PC}=$ Phycocyanin content of the extract $\left(\mathrm{mg} \mathrm{ml}^{-1}\right) ; \mathrm{A}_{615}=$ Absorbance at $615 \mathrm{~nm} ; \mathrm{A}_{652}=$ Absorbance at $652 \mathrm{~nm}$.

Table 1. Composition of experimental diets $[\mathrm{g} \%]$

\begin{tabular}{|c|c|c|c|c|}
\hline Ingredients & $\mathrm{T} 1$ & $\mathrm{~T} 2$ & T3 & $\mathrm{T} 4$ \\
\hline Fish meal & 54 & 54 & 54 & 54 \\
\hline Acetes meal & 14 & 14 & 14 & 14 \\
\hline Soyabean meal & 4 & 4 & 4 & 4 \\
\hline Squid meal & 5 & 5 & 5 & 5 \\
\hline Wheat gluten & 10 & 10 & 10 & 10 \\
\hline Fish oil & 2 & 2 & 2 & 2 \\
\hline Lecithin & 4 & 4 & 4 & 4 \\
\hline Vitamin-mineral mix & 2.5 & 2.5 & 2.5 & 2.5 \\
\hline Yeast & 3 & 3 & 3 & 3 \\
\hline Vitamin $\mathrm{C}$ & 0.3 & 0.3 & 0.3 & 0.3 \\
\hline Vitamin E & 0.2 & 0.2 & 0.2 & 0.2 \\
\hline Pigment/Wheat flour & 1 & 1 & 1 & 1 \\
\hline Total & 100 & 100 & 100 & 100 \\
\hline \multicolumn{5}{|c|}{ Proximate compostion (g\%) } \\
\hline Moisture & $8.75 \pm 0.88$ & $8.20 \pm 0.56$ & $8.45 \pm 0.33$ & $8.34 \pm 0.93$ \\
\hline \multicolumn{5}{|l|}{ In dry matter } \\
\hline Crude protein & $55.19 \pm 1.4$ & $55.23 \pm 1.3$ & $54.97 \pm 1.7$ & $55.34 \pm 0.9$ \\
\hline Crude lipid & $12.23 \pm 0.34$ & $12.15 \pm .56$ & $11.98 \pm 0.22$ & $12.21 \pm 0.12$ \\
\hline Ash & $16.19 \pm 0.21$ & $16.45 \pm 1.3$ & $17.32 \pm 0.4$ & $16.54 \pm 0.9$ \\
\hline Crude fiber & $2.49 \pm 0.12$ & $2.43 \pm 0.22$ & $2.65 \pm 0.43$ & $2.21 \pm 0.34$ \\
\hline
\end{tabular}

Composition of Vitamin-mineral mix (PREMIX PLUS) (quantity per $2.5 \mathrm{~kg}$ ): Vitamin A - $5500000 \mathrm{IU}$; Vitamin D3 - 1100000 IU; Vitamin B2 - $2000 \mathrm{mg}$; Vitamin E - 750 mg; Vitamin K - 1000 mg; Vitamin B6 - 1000 mg; Vitamin B12 - 6 нg; Calcium pantothenate - 2500 mg; Nicotinamide - 10 g; Choline chloride - 150 g; Mn - 27000 mg; I - 1000 mg; Fe - 7500 mg; Zn - 5000 mg; Cu - 2000 mg; Co - 450 mg; L-lysine - 10 g; DL-Methionine - 10 g; Selenium - 50 ppm
The liquid crude extract obtained was dried in a hot air over at $40^{\circ} \mathrm{C}$ for $24 \mathrm{~h}$ in a petridish yielding the solidified extract that was scraped carefully from the petridish to obtain crude phycocyanin flakes. The flakes were ground in a mixer to obtain fine powder and used for feed preparation.

The chlorophyll rich crude extract was obtained from freeze-dried Chlorella (Ocean Nutrition International LLC, USA). It was extracted using acetone as the solvent (Ilavarasi et al., 2012) and the crude extract was then concentrated in a rotary evaporator. The chlorophyll content in the crude extract was calculated using the formula (APHA, 2012):

$$
\text { Chlorophyll }\left(\mathrm{mg} \mathrm{m}^{-3}\right)=\frac{26.7\left[\left(\mathrm{OD}_{664}-\mathrm{OD}_{750}\right)-\left(\mathrm{OD}_{665}-\mathrm{OD}_{750}\right)\right] \cdot \mathrm{V}_{1}}{\mathrm{~V}_{2} \mathrm{X} \mathrm{L}}
$$

where $\mathrm{V}_{1}=$ Volume of the extract $(\mathrm{L}) ; \mathrm{V}_{2}=$ Volume of the sample $(\mathrm{m} 3) ; \mathrm{L}=$ Length of the cuvette $(\mathrm{cm})$; $\mathrm{OD}_{664}=$ Absorbance at $664 \mathrm{~nm} ; \mathrm{OD}_{750}=$ Absorbance at $750 \mathrm{~nm} ; \mathrm{OD}_{665}=$ Absorbance at $665 \mathrm{~nm}$

Carophyll Pink ${ }^{\mathrm{TM}} \quad(5 \%$ pure $)$ extracted from H. pluvialis (Ocean Nutrition International LLC, USA) was used as astaxanthin source.

\section{Experimental diets}

Four different types of experimental diets having crude protein $55 \%$ and crude lipid $12 \%$ were prepared (Table 1): T1: No pigment; T2:1\% Phycocyanin; T3: 1\% 
Chlorophyll and T4: 1\% Astaxanthin. For each treatment, diets were prepared by micro extrusion marumerisation technique (Barrows and Lellis, 2006). After carefully weighing the ingredients, they were thoroughly mixed in plastic buckets. Pigments were then added and the ingredients were again thoroughly mixed. This was followed by the addition of water to form a mash. The ingredient mash was then divided into two parts by weight. One part was cold extruded in $300 \mu$ mesh, at 15 revolutions per min each. The noodles obtained were then subjected to marumerisation in a cylindrical chamber with a rotating bottom plate. The bottom plate was rotated at a speed of 800 rotations per min for $90 \mathrm{~s}$ to obtain microdiets of $300 \mu \mathrm{m}$ particle size. The second part of the mash was cold extruded in a $500 \mu \mathrm{m}$ mesh and then subjected to marumerisation, with conditions being the same as for the first part of the mash. This yielded microdiets of $500 \mu \mathrm{m}$ particle size. The microdiets were carefully kept to dry in hot air oven at $40^{\circ} \mathrm{C}$ for $1 \mathrm{~h}$ and stored in zip-lock covers until use. The proximate analysis for crude protein (Kjeldahl nitrogen $\times 6.25$ ), total fat (ether extraction), ash (residue after $4 \mathrm{~h}$ at $600^{\circ} \mathrm{C}$ ), moisture (weight loss after drying at $105^{\circ} \mathrm{C} 4-5 \mathrm{~h}$ ) and crude fibre (acid-alkali wash) was carried out following standard methods (AOAC, 1995).

\section{Experimental fish and feeding}

Four hundred and twenty L. calcarifer larvae at 16 days post-hatch (dph) were used for the feeding experiment. Thirty-five larvae were randomly stocked in 12 tubs (four treatments having three replicates each) of volume 301 each. Co-feeding of Artemia nauplii and experimental microdiets was continued until the larvae were completely weaned to experimental microdiets on 21 $\mathrm{dph}$. The feeding was continued for 30 days (16 to $46 \mathrm{dph}$ ). Water quality parameters were maintained optimally.

\section{Survival study and growth performance}

The following formulae were used to evaluate the survival and growth performance of the larvae:

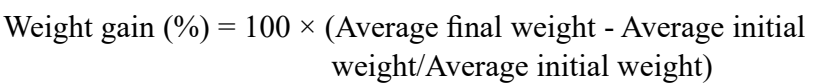

Specific growth rate $\left(\%\right.$ day $\left.^{-1}\right)=[(\ln$ Average final weight $-\ln$ Average initial weight)/Time (days) $\mathrm{x} 100]$

Cannibalism $(\%)=100 \times\{$ Initial number of fish $-($ Final number of fish + Number of dead fish registered) $\}$ /Initial number of fish

Coefficient of variation $(\%)=($ Standard deviation of individual weight/ Mean individual weight) $\times 100$
Size heterogeneity (weight) = Final coefficient of variation/ Initial coefficient of variation

Survival rate $(\%)=($ Final number of fish $\mathrm{x} 100) /$ Initial number of fish)

Fulton's condition equation was used to find out the condition factor:

$$
\mathrm{K}=\left(\mathrm{W} \times 10^{5}\right) / \mathrm{TL}^{3}
$$

where $\mathrm{K}$ is the condition factor, $\mathrm{W}$ is weight $(\mathrm{g})$ and TL is average total length $(\mathrm{mm})$.

\section{Antioxidant enzymes activities}

On termination of the feeding experiment, three larvae from each tank were weighed and homogenised in phosphate buffered saline (PBS) solution with a $\mathrm{pH}$ of 7.6, kept in an ice-water bath. After centrifugation $(13,000 \mathrm{~g}$, $5^{\circ} \mathrm{C}, 15 \mathrm{~min}$ ), the supernatant was used for determination of enzyme activities. Superoxide dismutase (Superoxide: Superoxide oxidoreductase, EC 1.15.1.1) was assayed in the homogenate by the method of Marklund and Marklund (1974). The enzyme activity was expressed as units per $\mathrm{mg}$ of protein in tissues. The reaction was initiated by the addition of $0.5 \mathrm{ml}$ pyrogallol reagent and the change in optical density was measured at $480 \mathrm{~nm}$ for $3 \mathrm{~min}$. Fifty percent inhibition of pyrogallol by the enzyme was taken as one enzyme unit. Catalase (Hydrogen peroxide: Hydrogen-peroxide oxidoreductase, EC 1.11.1.6) activity was assayed by the method of Sinha (1972). Absorbance was read at $570 \mathrm{~nm}$. Catalase activity was expressed as micromoles of $\mathrm{H}_{2} \mathrm{O}_{2}$ consumed per minute per $\mathrm{mg}$ of protein.

\section{Bacterial challenge study}

For determination of $\mathrm{LC}_{50}$ value, purified Vibrio alginolyticus culture from glycerol stock was revived in Zobell-Marine broth. The bacteria were plated on thiosulphate citrate bile salt sucrose (TCBS) agar by the spread-plate technique to obtain single colony. A single colony was taken and again regrown in tryptic soy broth (TSB) supplemented with $2 \% \mathrm{NaCl}$. The culture broth was centrifuged at $3000 \mathrm{~g}$ for $10 \mathrm{~min}$. The pellets were suspended in sterile saline $(0.9 \% \mathrm{NaCl}, \mathrm{pH} 7.4)$ and the OD of the solution was adjusted to 0.6 . This corresponded to a count of $1.40 \times 10^{8} \mathrm{cfu} \mathrm{ml}^{-1}$, confirmed by total plate count. The bacterial cells were then diluted to get different concentrations required for the experiment. Eighty larvae that were being fed the control experimental diet (Table 1) and were from the same source as the experimental fish were used for $\mathrm{LC}_{50}$ study. They were distributed randomly into 8 groups with 10 larvae each. Each of seven groups were bath challenged by bacteria at concentrations of $1.4 \times 10^{1}$ to $1.4 \times 10^{7} \mathrm{cfu} \mathrm{ml}^{-1}$ for $1 \mathrm{~h}$. The control group was maintained in sterile seawater. The larvae were 
monitored for $96 \mathrm{~h}$ and in case of mortality, the causative agent was confirmed by re-isolating $V$. alginolyticus from the moribund larvae. $\mathrm{LC}_{50}$ value was calculated as per the trimmed Spearman-Karber method (Hamilton et al., 1977).

For the bacterial challenge experiment, 10 larvae from each replicate tank were immersed for $1 \mathrm{~h}$ in seawater containing bacterial cells. Larvae were then maintained separately in 101 tubs of seawater and monitored for mortality for the following 7 days. From the data of the percentage mortality, relative percentage survival (RPS) against the control group was calculated at the end of 7 days of challenge, using the following formula (Ahmad et al., 2016):

\section{RPS $=1$-(Percentage mortality in treatment/ Percentage mortality in control) $\times 100$}

\section{Statistical analysis}

To validate the reproducibility of results, each assay was done in triplicate. The results were treated by oneway analysis of variance (ANOVA) using SPSS v. 16. Comparison among different treatments was made using Duncan's Multiple Range Test (DMRT). All analyses were performed considering a level of $95 \%$ of confidence $(p<0.05)$.

\section{Results}

\section{Feed pigments and pigment extraction}

The phycocyanin content in the crude extract was $1.3 \mathrm{mg} \mathrm{ml}^{-1}$ that corresponded to the yield of $65 \mathrm{mg} \mathrm{g}^{-1}$ freeze dried Spirulina. The chlorophyll content in the crude extract was $0.0645 \mathrm{mg} \mathrm{ml}^{-1}$ corresponding to a yield of $6.45 \mathrm{mg} \mathrm{g}^{-1}$ freeze dried Chlorella (Fig. 1).

\section{Experimental diets}

The extracted pigments were concentrated and used in the development of diets of different colours. Concentrated pigment extracts were added to the feed at $1 \%$ inclusion level (Fig. 2). No pigment was added in control diet (T1), which retained the brown colour of the basal diet. The phycocyanin and chlorophyll pigmented feeds developed green (T2) and black (T3) colour

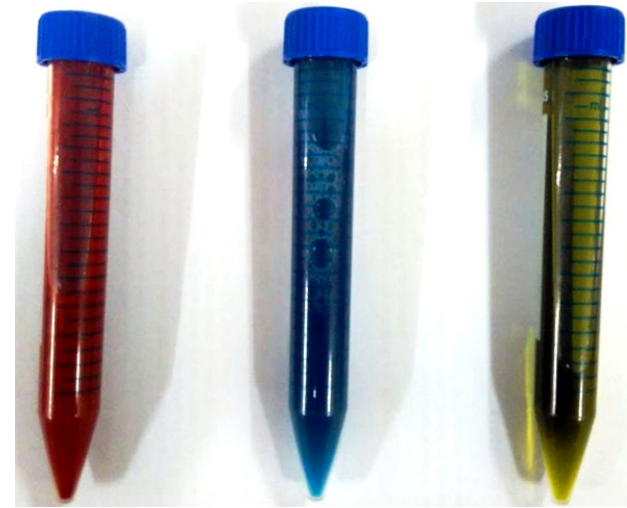

Fig. 1. (a) Crude Astaxanthin, (b) Phycocyanin and (c) Chlorophyll extracts used for diet preparation
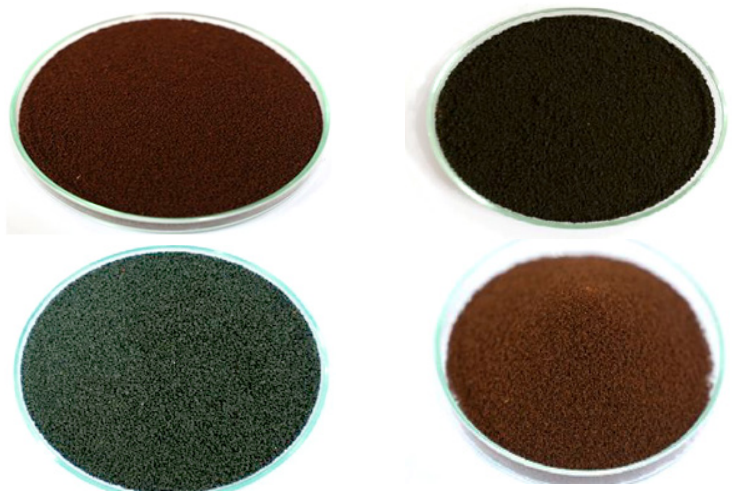

Fig. 2. Experimental diets prepared for the feeding trial using different pigments in crude form as additives.

(a) $1 \%$ Astaxanthin, (b) $1 \%$ Chlorophyll, (c) $1 \%$ Phycocyanin and (d) Control diet with no pigment additive

respectively. The astaxanthin based feed developed red colour (T4).

Growth performance, size heterogeneity and condition factor

There was no significant difference $(p<0.05)$ in the percentage weight gain, specific growth rate, daily growth rate, coefficient of variation, size heterogeneity and condition factor in the different experimental groups (Table 2).

Table 2. Weight gain (\%), specific growth rate (GR), average daily growth ( $\left.\mathrm{mg} \mathrm{day}^{-1}\right)$, coefficient of variation $(\%)$, size heterogeneity and condition factor $(\mathrm{K})$ of $L$. calcarifer larvae

\begin{tabular}{lllllll}
\hline Treatment & Weight gain (\%) & $\begin{array}{l}\text { Specific growth } \\
\text { rate }\left(\% \text { day }^{-1}\right)\end{array}$ & $\begin{array}{l}\text { Average daily } \\
\text { growth }\left(\mathrm{mg} \mathrm{day}^{-1}\right)\end{array}$ & $\begin{array}{l}\text { Coefficient of } \\
\text { variation }(\%)\end{array}$ & $\begin{array}{l}\text { Size heterogeneity } \\
(\%)\end{array}$ & $\begin{array}{l}\text { Condition } \\
\text { factor }(\mathrm{K})\end{array}$ \\
\hline T1 & $2308.91 \pm 507.47$ & $4.54 \pm 0.2$ & $4.497 \pm 1.06$ & $61.28 \pm 10.23$ & $1.18 \pm 0.19$ & $2.64 \pm 0.15$ \\
T2 & $1809.59 \pm 183.98$ & $4.33 \pm 0.13$ & $3.85 \pm 0.32$ & $60.91 \pm 6.99$ & $1.18 \pm 0.13$ & $2.85 \pm 0.30$ \\
T3 & $2642.17 \pm 699.55$ & $4.59 \pm 0.36$ & $4.69 \pm 1.27$ & $59.12 \pm 4.70$ & $1.14 \pm 0.09$ & $2.68 \pm 0.20$ \\
T4 & $1959.58 \pm 65.58$ & $4.60 \pm 0.04$ & $4.46 \pm 0.12$ & $53.86 \pm 7.64$ & $1.04 \pm 0.14$ & $2.39 \pm 0.04$ \\
\hline
\end{tabular}

Values represent Mean \pm SE. Mean values are data of three replicates $(n=3)$. Values in the same column with no significant difference ( $<<0.05)$ have no superscript. T1 - Control; T2 - 1\% Phycocyanin, T3 - 1\% Chlorophyll, T4 - 1\% Astaxanthin 


\section{Survival and cannibalism}

The survival (\%) of larvae in the different experimental groups was highest $(p<0.05)$ in the astaxanthin fed groups compared to other groups (Fig. 3). The group fed the chlorophyll pigmented feed exhibited significantly lower survival $(\mathrm{p}<0.05)$ than all the other groups. The mortality due to cannibalism over the 30 days feeding experiment was significantly lower in $\mathrm{T} 2$ and $\mathrm{T} 4$ groups compared to the control group. However, there was no significant difference between T2 and T4 (Fig. 4).

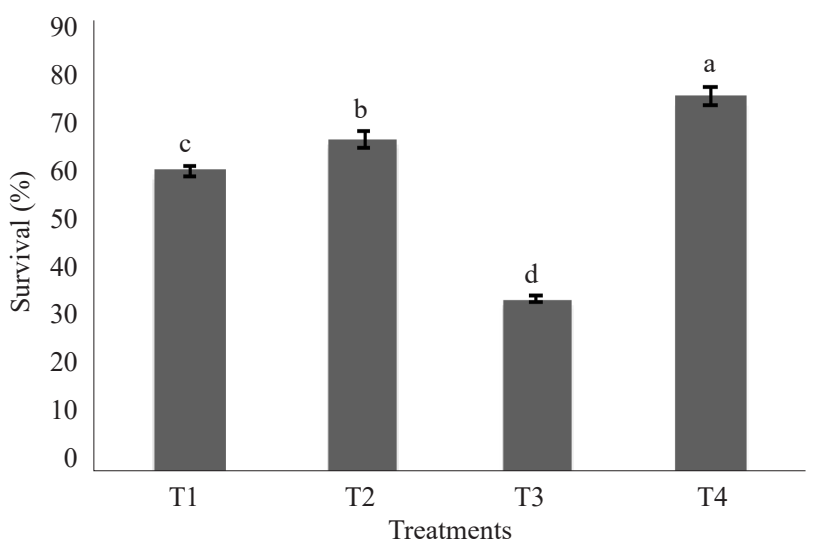

Fig. 3. Percentage survival of different experimental groups. Mean values $(\mathrm{n}=3)$ in the experimental group with different superscripts ( $\mathrm{a}, \mathrm{b}, \mathrm{c}$ and d) differ significantly $(\mathrm{p}<0.05)$. Data expressed as Mean \pm SE. T1 - Control; T2 - 1\% Phycocyanin, T3 - 1\% Chlorophyll, T4 - 1\% Astaxanthin

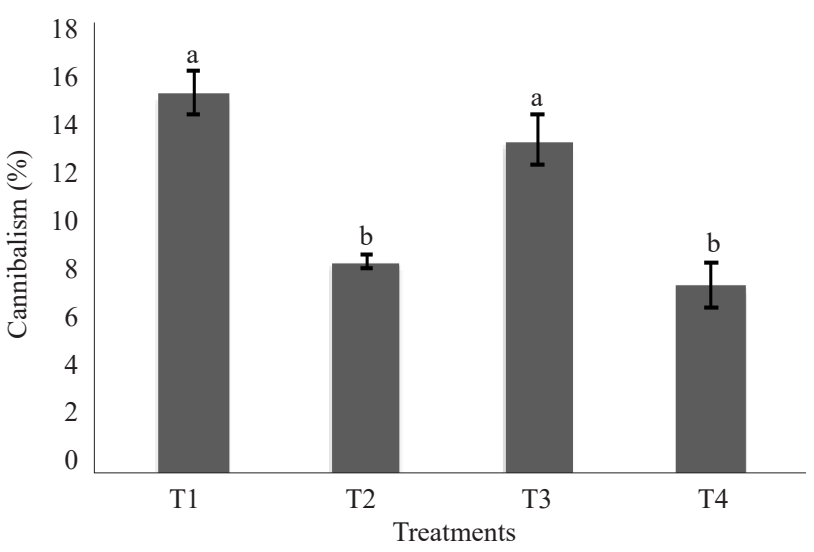

Fig. 4. Mortality due to cannibalism (\%) in different experimental groups. Mean values $(n=3)$ in the experimental group with different superscripts $(\mathrm{a}, \mathrm{b})$ differ significantly $(\mathrm{p}<0.05)$. Data expressed as Mean \pm SE. T1 - Control; T2 - 1\% Phycocyanin, T3 - 1\% Chlorophyll, T4 - 1\% Astaxanthin

\section{Antioxidant enzyme activity}

Both superoxide dismutase and catalase enzymes showed significantly reduced activity in the group fed phycocyanin pigmented feed (T2). The activities of the two enzymes in the other three experimental groups were not significantly different from each other (Fig. 5).

\section{Challenge study}

The $\mathrm{LD}_{50}$ value obtained after 5 days of observation period for the viable cells of $V$. alginolyticus to fingerlings was found to be $1.4 \times 10^{4.5} \mathrm{cfu} \mathrm{ml}^{-1}$. After immersion challenge by the same concentration of bacteria in the experimental fish, the first mortality was observed at $8 \mathrm{~h}$. At the end of the 7 days challenge period, the groups fed phycocyanin (T2) and astaxanthin (T4) pigmented diets exhibited significantly lower mortality $(\mathrm{p}<0.05)$. Mortality was highest in the control group but it was not significantly different from the group fed chlorophyll pigmented feed. The relative percentage of survival (RPS) for the treatment groups (T2, T3 and T4) was calculated against control group that was assumed to have $0 \%$ survival. The RPS was highest in the group fed the astaxanthin-pigmented diet followed by phycocyanin-pigmented diet (Fig. 6).

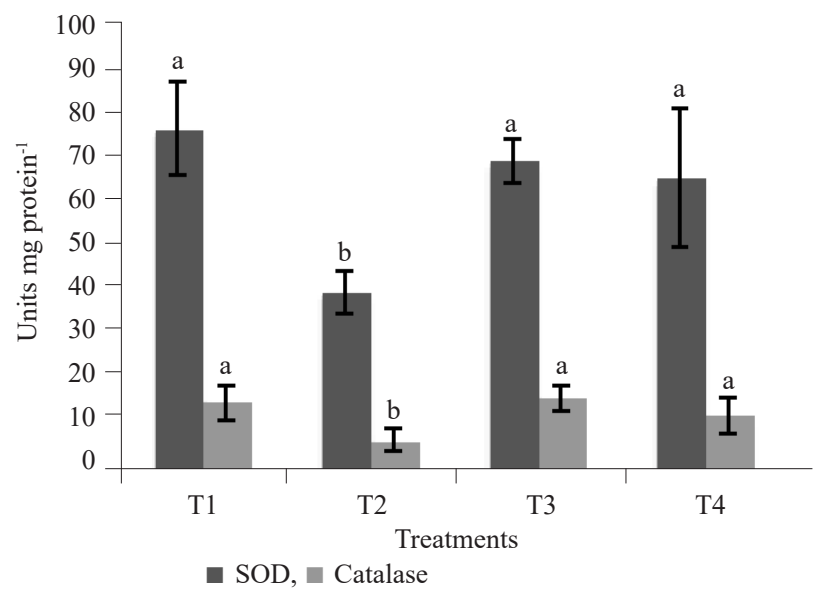

Fig. 5. Status of anti-oxidant enzymes of $L$. calcarifer larvae fed different experimental diets. Mean values $(n=3)$ in the experimental group with different superscripts $(a, b)$ differ significantly $(p<0.05)$. Data expressed as Mean \pm SE. T1 - Control; T2 - 1\% Phycocyanin, T3 - 1\% Chlorophyll, T4 - 1\% Astaxanthin

\section{Discussion}

In fish larval nutrition, the microalgae are either used directly or as food of live prey (Brown et al., 1997). Microalgae may also be used to obtain crude extract for use in aquafeeds (Apt and Behrens, 1999). In the present study, effect of microalgal crude extracts on cannibalism, growth performance, survival and disease resistance of seabass larvae was evaluated.

Efficiency of extraction of phycocyanin from Spirulina is affected by the cellular disruption method, type of solvent, biomass-solvent ratio and extraction time 


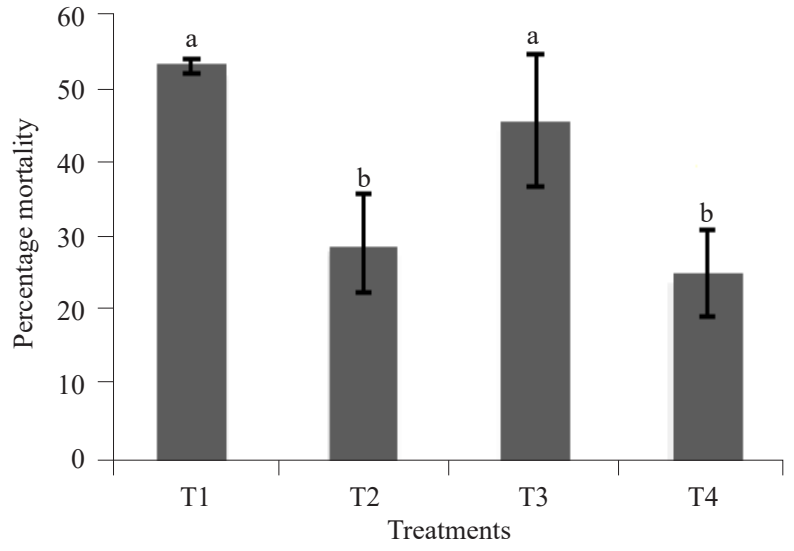

(a)

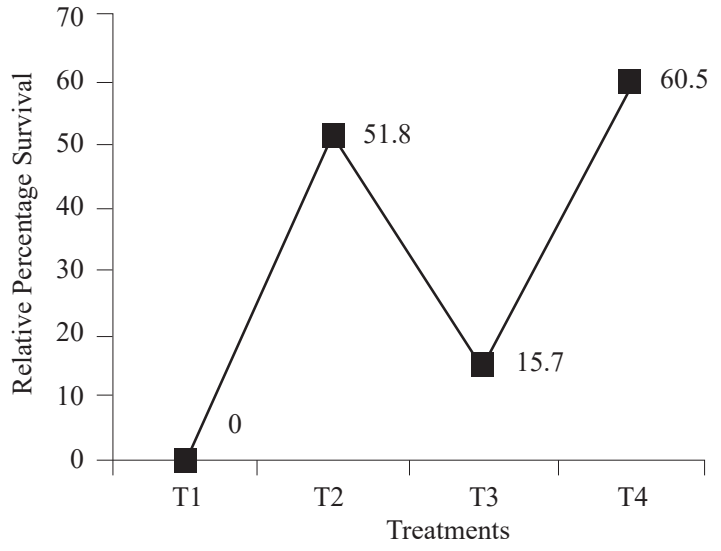

(b)

Fig. 6. Percentage mortality (A) and Relative percentage of survival (B) compared to Control group (T1). Mean values ( $\mathrm{n}=3$ ) with different superscripts $(a, b)$ differ significantly $(p<0.05)$ and with the same superscripts do not differ significantly. Data are expressed as Mean \pm SE. T2 - 1\% Phycocyanin, T3 - 1\% Chlorophyll, T4 - 1\% Astaxanthin

(Abalde et al., 1998; Reis et al., 1998). Common methods for extraction and purification of phycocyanin involve break-up of cells using high-pressure homogenisation, sonication, freeze thawing, or enzymatic treatment (Eriksen, 2008). We obtained phycocyanin yield of $65 \mathrm{mg} \mathrm{g}^{-1}$ at a solvent biomass ratio of 1:50 by rapid freesing and thawing method. Dried Spirulina has shown lower yield of phycocyanin as compared to its fresh biomass (Sarada et al., 1999). However, we found no such reduction in the yield compared to previous studies that used fresh Spirulina (Minkova et al., 2003; Sandeep et al., 2013). Chlorophyll is a lipid soluble compound and is usually extracted in organic solvents (Simon and Helliwell, 1998). Usually acetone is used as the solvent with duration of extraction and number of extraction steps affecting the yield of chlorophyll (Schumann et al., 2005). Cell disruption of $C$. vulgaris by ultrasound bath yielded chlorophyll content of $13.10 \mathrm{ug} \mathrm{ml}^{-1}$ in the extract (Seyfabadi et al., 2011). In the present study, instead of ultrasound we used mechanical stirring in acetone, yielding chlorophyll content of $6.45 \mathrm{mg} \mathrm{g}^{-1}$ dry Chlorella. The use of astaxanthin in aquaculture has been studied in great detail for decades. Astaxanthin is known as the natural colourant giving some fish and crustaceans their characteristic body colour (Fujii et al., 2010). Although the present study did not focus on the pigmentation of larvae fed with astaxanthin-enriched diet, the same source of astaxanthin (Carophyll Pink ${ }^{\mathrm{TM}}$ ) was used.

Different studies carried out to evaluate the effect of astaxanthin on growth performance of fish reveal conflicting results (Amar et al., 2001; Seyedi et al., 2013). We found no significant difference in the growth performance of different experimental groups. A number of studies suggest that the growth promotion by astaxanthin is not direct and depends on other extraneous variables (Storebakken and Choubert, 1991; Christiansen et al., 1994). Indeed, it will be interesting to decipher the factors affecting the capacity of astaxanthin to improve growth performance. Although bioactive properties have been associated with both chlorophyll (Simonich et al., 2008) as well as phycocyanin (Hayashi et al., 2006), the growth promoting effects of these bioactive compounds in fish larvae is unknown. The present study represents the first attempt to evaluate the effect of these dietary compounds on the growth performance of seabass larvae. We found no significant effect on the growth performance when the seabass larvae were fed chlorophyll or phycocyanin extracts.

Astaxanthin and phycocyanin fed groups exhibited higher survival and the chlorophyll fed group showed lower survival than the control group. Dietary astaxanthin has been observed to improve the survival of fish in earlier studies (Chuchird et al., 2015). The improvement of survival in the group fed dietary astaxanthin may be attributed to a number of reasons: the provitamin A function of astaxanthin (Christiansen et al., 1994) and immune stimulation (Jyonouchi et al., 1995). Phycocyanin obtained from $S$. platensis has been reported to exhibit antioxidant activity (Soni et al., 2008). Feeding phycocyanin may attribute better survival of larvae through antioxidant and radical scavenging properties of phycocyanin help in reducing the oxidative stress. This is further supported by our observation of reduction in the antioxidant enzyme activities in the treatment group fed phycocyanin pigmented feed. The higher mortality in T3 may be attributed to lipid soluble feed deterrents, that may have been activated or co-extracted along with chlorophyll. Similar feed deterrent compounds have been 
observed from other marine autotrophs (Paul, 1987). The presence of these compounds in the feed may have reduced the feeding activity of larvae in T3. As starvation induces cannibalism (Folkvord, 1991), the same treatment group (T3) also reported the highest cannibalism incidences. Therefore, higher cannibalism in T3 supports our assumption that the presence of chlorophyll reduced the palatability of microdiets.

Cannibalism was markedly reduced when the larvae were weaned on astaxanthin and phycocyanin based diets. This may be due to better visibility and acceptance of feed particles inducing reduction of prey vulnerability through improved prey escape skills (Baras and Jobling, 2002). Although a varied difference in the cannibalism in the treatment groups was observed, we found no difference in the size heterogeneity of the treatments. This may be because of the reduction in the size heterogeneity due to cannibalism observed in control group and T3 group (Baras and Jobling, 2002).

Immunostimulants offer alternative to drugs in the aquaculture industry, which are used to avoid bacterial disease outbreaks. $V$. alginolyticus is a bacterium of wide distribution, which is known to infect cultured finfish and shellfish (Sharma et al., 2012). We observed reduced mortality after challenge in fish fed phycocyanin and astaxanthin pigmented feeds. The higher resistance to $V$. alginolyticus infection could be attributed to incorporation of astaxanthin and phycocyanin, which are known to have immunostimulant effects when fed through diet (Hayashi et al., 2006; Chuchird et al., 2015).

\section{Acknowledgements}

The authors are grateful to the Director, ICAR-CIBA, Chennai for providing support and facilities to carry out this research.

\section{References}

Abalde, J., Betancourt, L., Torres, E., Cid, A. and Barwell, C. 1998. Purification and characterisation of phycocyanin from the marine cyanobacterium Synechococcus sp. IO9201. Plant Sci., 136:109-120. https://doi.org/10.1016/ S0168-9452(98)00113-7.

Ahmad, I., Verma, A. K., Rani, A. B., Rathore, G., Saharan, N. and Gora, A. H. 2016. Growth, non-specific immunity and disease resistance of Labeo rohita against Aeromonas hydrophila in biofloc systems using different carbon sources. Aquaculture, 457: 61-67. https://doi.org/10.1016/j. aquaculture.2016.02.011.

Amar, E. C., Kiron, V., Satoh, S. and Watanabe, T. 2001. Influence of various dietary synthetic carotenoids on biondefence mechanisms in rainbow trout, Oncorhynchus mykiss (Walbaum). Aquac. Res., 32: 162-173. 10.1046/j.1355557x.2001.00051.x.
APHA 2012. Standard methods for the examination of water and waste water. $22^{\text {nd }}$ edn. American Public Health Association, New York, USA.

AOAC 1995. Official methods of analysis, $18^{\text {th }}$ edn. Association of Official Analytical Chemists, Benjamin Franklin Station, Washington DC, USA.

Apt, K. E. and Behrens, P. W. 1999. Commercial developments in microalgal biotechnology. J. Phycol., 35: 215-226. 10.1046/j.1529-8817.1999.3520215.x.

Baras, E. and Jobling, M. 2002. Dynamics of intracohort cannibalism in cultured fish. Aquac. Res., 33: 461-479. 10.1046/j.1365-2109.2002.00732.x.

Barlow, C. G., Pearce, M. G., Rodgers, L. J. and Clayton, P. 1995. Effects of photoperiod on growth, survival and feeding periodicity of larval and juvenile barramundi Lates calcarifer (Bloch). Aquaculture, 138: 159-168. DOI: 10.1016/0044-8486(95)01073-4.

Barrows, F. T. and Lellis, W. A. 2006. Effect of diet processing method and ingredient substitution on feed characteristics and survival of larval walleye, Sander vitreus. J. World Aquac. Soc., 37: 154-60. doi.org/10.1111/j.1749-7345.20 06.00021.x

Bennett, A. and Bogorad, L. 1973. Complementary chromatic adaptation in a filamentous blue-green alga. J. Cell. Biol., 58: 419-435.

Bhat, V. B. and Madyastha, K. M. 2001. Scavenging of peroxynitrite by phycocyanin and phycocyanobilin from Spirulina platensis: protection against oxidative damage to DNA. Biochem. Biophys. Res. Commun., 285: 262-266. https://doi.org/10.1006/bbrc.2001.5195.

Brown, M. R. and Jeffrey, S. W., Volkman, J. K. and Dunstan, G. A. 1997. Nutritional properties of microalgae for mariculture. Aquaculture, 151: 315-331. https://doi.org/10. 1016/S0044-8486(96)01501-3.

Christiansen, R., Lie, O. and Torrissen, O. J. 1994. Effect of astaxanthin and vitamin A on growth and survival during first feeding of Atlantic salmon, Salmo salar L. Aquac. Res., 25: 903-914. 10.1111/j.1365-2109.1994.tb01352.x.

Chuchird, N., Rorkwiree, P. and Rairat, T. 2015. Effect of dietary formic acid and astaxanthin on the survival and growth of Pacific white shrimp (Litopenaeus vannamei) and their resistance to Vibrio parahaemolyticus. Springer Plus, 4: 440 pp. http://doi.org/10.1186/s40064-015-1234-x.

Dashwood, R., Negishi, T., Hayatsu, H., Breinholt, V., Hendricks, J. and Bailey, G. 1998). Chemopreventive properties of chlorophylls towards aflatoxin B 1: a review of the antimutagenicity and anticarcinogenicity data in rainbow trout. Mut. Res., 399(2): 245-253.

Eriksen, N. T. 2008. Production of phycocyanin-a pigment with applications in biology, biotechnology, foods and medicine. Appl. Microbiol. Biotechnol., 80: 1-14. DOI: 10.1007/s00253-008-1542-y. 
Folkvord, A. 1991. Growth, survival and cannibalism of cod juveniles (Gadus morhua): effects of feed type, starvation and fish size. Aquaculture, 97: 41-59. https://doi. org/10.1016/0044-8486(91)90278-F.

Fujii,K.,Nakashima,H.,Hashidzume,Y.,Uchiyama,T.,Mishiro,K. and Kadota, Y. 2010. Potential use of the astaxanthinproducing microalga, Monoraphidium sp. GK12, as a functional aquafeed for prawns. J. Appl. Phycol.. 22: 363369. DOI: $10.1007 / \mathrm{s} 10811-009-9468-\mathrm{z}$.

Guerin, M., Huntley, M. E. and Olaizola, M. 2003. Haematococcus astaxanthin: applications for human health and nutrition. Trends Biotechnol., 21: 210-216. https://doi. org/10.1016/S0167-7799(03)00078-7.

Hamilton, M. A., Russo, R. C. and Thurston, R. V. 1977. Trimmed Spearman-Karber method for estimating median lethal concentrations in toxicity bioassays. Environ. Sci. Technol., 11: 714-719. DOI: 10.1021/es60130a004.

Hamre, K., Yufera, M., Ronnestad, I., Boglione, C., Conceicao, L. E. and Izquierdo, M. 2013. Fish larval nutrition and feed formulation: knowledge gaps and bottlenecks for advances in larval rearing. Rev. Aquac., 5: S26-S58. https:// doi.10.1111/j.1753-5131.2012.01086.x.

Hayashi, O., Ono, S., Ishii, K., Shi, Y., Hirahashi, T.and Katoh, T. 2006. Enhancement of proliferation and differentiation in bone marrow hematopoietic cells by Spirulina (Arthrospira) platensis in mice. J. Appl. Phycol., 18: 4756. 10.1007s10811-005-9014-6.ss

Ilavarasi, A., Pandiaraj, D., Mubarakali, D., Ilyas, M. H. and Thajuddin, N. 2012. Evaluation of efficient extraction methods for recovery of photosynthetic pigments from microalgae. Pakistan J. Biol. Sci., 15: 883-888. 10.3923/ pjbs.2012.883.888.

Jyonouchi, H., Sun, S., Tomita, Y. and Gross, M. D. 1995. Astaxanthin, a carotenoid without vitamin A activity, augments antibody response in cultures including T-helper cell clones and suboptimal doses of antigen. J. Nutr., 125: 2483-2492. DOI: $10.1093 / \mathrm{jn} / 125.10 .2483$.

Kailasam, M., Thirunavukkarasu, A. R., Abraham, M., Chandra, P. K. and Subburaj, R. 2002. Influence of size variation and feeding on cannibalism of Asian seabass Lates calcarifer (Bloch) during hatchery rearing. Indian J. Fish., 49: 107-111.

Kailasam, M., Thirunavukkarasu, A. R., Selvaraj, S. and Stalin, P. 2007. Effect of delayed initial feeding on growth and survival of Asian seabass Lates calcarifer (Bloch) larvae. Aquaculture, 271(1-4): 298-306. doi.org/10.1016/j. aquaculture.2007.05.005.

Marklund, S. and Marklund, G. 1974. Involvement of the superoxide anion radical in the autoxidation of pyrogallol and a convenient assay for superoxide dismutase. FEBS J., 47:469-474. 10.1111/j.1432-1033.1974.tb03714.x.

Minkova, K. M., Tchernov, A. A., Tchorbadjieva, M. I., Fournadjieva, S. T., Antova R. E. and Busheva, M. C.
2003. Purification of C-phycocyanin from Spirulina (Arthrospira) fusiformis. J. Biotechnol., 102: 55-59. https:// doi.org/10.1016/S0168-1656(03)00004-X.

Patil, G. and Raghavarao, K. S. M. S. 2007. Aqueous two phase extraction for purification of C-phycocyanin. Biochem. Engin., J., 34: 156-164. https://doi.org/10.1016/j.bej.2006. 11.026 .

Paul, V. J. 1987. Feeding deterrent effects of algal natural products. Bull. Mar. Sci., 41: 514-522.

Reis, A., Mendes, A., Lobo-Fernandes, H., Empis, J. A and, Novais, J. M. 1998. Production, extraction and purification of phycobiliproteins from Nostoc sp. Bioresource Technol., 66: 181-187. https://doi.org/10.1016/S0960-8524 (98)00064-9.

Sandeep, K. P., Shukla, S. P., Harikrishna, V., Muralidhar, A. P., Vennila, A., Purushothaman, C. S. and Kumar, R. R. 2013. Utilisation of inland saline water for Spirulina cultivation. J. Water Reuse Desalin., 3: 346-356. https:// doi.org/10.2166/wrd.2013.102.

Sarada, R. M. G. P., Pillai, M. G. and Ravishankar, G. A. 1999. Phycocyanin from Spirulina sp. influence of processing of biomass on phycocyanin yield, analysis of efficacy of extraction methods and stability studies on phycocyanin. Process Biochem., 34: 795-801. https://doi. org/10.1016/S0032-9592(98)00153-8.

Schumann, R., Haubner, N., Klausch, S. and Karsten, U. 2005. Chlorophyll extraction methods for the quantification of green microalgae colonising building facades. Int. Biodeterior. Biodegr., 55: 213-222. https://doi.org/10.10 16/j.ibiod.2004.12.002.s

Seyedi, S. M., Sharifpour, I., Ramin, M. and Jamili, S. 2013. Effect of dietary astaxanthin on survival, growth, pigmentation clownfish, Amphiprion ocellaris, Cuvier. Indian J. Fundam. Appl. Life Sci., 3: 391-395.

Seyfabadi, J., Ramezanpour, Z. and Khoeyi, Z. A. 2011. Protein, fatty acid and pigment content of Chlorella vulgaris under different light regimes. J. Appl. Phycol., 23: 721-726. DOI: 10.1007/s10811-010-9569-8.

Sharma, K., Ramachandra, S., Rathore, G., Verma, D. K., Sadhu, N. and Philipose, K. K. 2012. Vibrio alginolyticus infection in Asian seabass (Lates calcarifer, Bloch) reared in open sea floating cages in India. Aquac. Res., 44: 86-92. 10.1111/j.1365-2109.2011.03013.x.

Simon, D. and Helliwell, S. 1998. Extraction and quantification of chlorophyll a from freshwater green algae. Water Res., 32: 2220-2223. https://doi.org/10.1016/S0043-1354 (97)00452-1.

Simonich, M. T., McQuistan, T., Jubert, C., Pereira, C., Hendricks, J. D., Schimerlik, M., Zhu, B., Dashwood, R. H., Williams, D. E. and Bailey, G. S. 2008. Low-dose dietary chlorophyll inhibits multi-organ carcinogenesis in 
the rainbow trout. Food. Chem. Toxicol., 46: 1014-1024. https://doi.org/10.1016/j.fct.2007.10.034.

Sinha, A. K. 1972. Colorimetric assay of catalase. Anal. Biochem., 47: 389-394. https://doi.org/10.1016/0003-2697 (72)90132-7.

Sivasankari, S., Naganandhini, N. and Ravindran, D. 2014. Comparison of different extraction methods for phycocyanin extraction and yield from Spirulina platensis. Int. J. Curr. Microbiol. Appl. Sci., 3: 904-909.

Soni, B., Trivedi, U. and Madamwar, D. 2008. A novel method of single step hydrophobic interaction chromatography for the purification of phycocyanin from Phormidium fragile and its characterisation for antioxidant property. Bioresour. Technol., 99: 188-194. https://doi.org/10.1016/j.biortech. 2006.11.010.
Spolaore, P., Joannis-Cassan, C., Duran, E. and Isambert, A 2006. Commercial applications of microalgae. J. Biosci. Bioengin., 101: 87-96. https://doi.org/10.1263/jbb.101.87.

Storebakken, T. and Choubert, G. 1991. Flesh pigmentation of rainbow trout fed astaxanthin or canthaxanthin at different feeding rates in freshwater and saltwater. Aquaculture, 95: 289-295. https://doi.org/10.1016/0044-8486(91)90094-N.

Vassallo-Agius, R., Imaizumi, H., Watanabe, T., Yamazaki, T., Satoh, S. and Kiron, V. 2001. The infl uence of astaxanthin supplemented dry pellets on spawning of striped jack. Fish. Sci., 67: 260-270.

Yoshida, A., Takagaki, Y. and Nishimune, T. 1996. Enzyme immunoassay for phycocyanin as the main component of Spirulina color in foods. Biosci. Biotechnol. Biochem., 60: 57-60. http://doi.org/10.1271/bbb.6.

Date of Receipt $\quad$ : 21.04 .2018

Date of Acceptance : 11.02 .2019 